\title{
Beyond Borders: Paradoxes and Challenges
}

\author{
Yves Gambier* \\ University of Turku, Finland \\ 4 Koskenniemenkatu, Turku, 20500, Finland
}

Received 22.11.2014, received in revised form 14.12.2014, accepted 21.01.2015

The Translation and Interpreting Studies are nowadays facing professional, socio-professional, sociopolitical, technological, and pedagogical challenges. The article seeks to answer three questions based on these challenges:

- Why do we need a media history of translation?

- To what extent is the new relationship between oral and written codes disturbing Translation Studies?

- What could the possible ethical and methodological implications be?

These three issues have a common denominator: Information and Communication Technology (ICT) which is blurring our traditional borders and categories

Keywords: digital culture, language categorization, media history, oral/written codes, text, translator ethics.

Research area: philology.

\section{Introduction}

Translation and Interpreting Studies (understood as a field of research and as training) are facing several challenges:

- Professional challenges, with new practices (localization, trans-editing, multilingual technical writing, revision, etc.)

- Socio-professional challenges, because of the large volume of documentation to be translated and the new nonprofessionals involved in the work (amateurs in crowdsourcing, fansubbers and fandubbers, activist translators in networks, children in language brokering, etc.)
- Socio-political challenges, when one considers alternative options to translation for cross-cultural communications, such as language learning, passive bilingualism, the use of a lingua franca, etc.

- Technological challenges, thanks to different tools and software which are changing user expectations and responses

- Pedagogical challenges, with more and more multimodal "texts" and hybridity between orality and literacy - implying, for instance, a rethink about priorities: Do we still need to teach simultaneous interpreting after consecutive? Or train

(C) Siberian Federal University. All rights reserved

* Corresponding author E-mail address: Yves.Cambier@utu.fi 
in translation before interpreting? New translation and interpreting practices are maybe less separated than we usually believe.

Certainly, in the changing landscape, the role and the position of the translators and interpreters must be reconsidered.

My intervention will seek to answer three questions based on these challenges:

- Why do we need a media history of translation?

- To what extent is the new relationship between oral and written codes disturbing Translation Studies?

- What could the possible ethical and methodological implications be?

These three issues have a common denominator: Information and Communication Technology (ICT) which is blurring our traditional borders and categories.

\section{A media history of translation}

When thinking of crowdsourcing or collaborative translation done by an indefinite group of amateurs (with or without formal training in translation), two remarks come to mind:

- It calls into question a certain ideology which assumes that translation is always an individual act, focused on a written text, and takes the translator as a kind of substitute for the author;

- it recalls certain working modes of the past, such as team work, by pairs or more, as practised from the $12^{\text {th }}$ century onwards (e.g. one working from Arabic into spoken Romance, the other one from spoken Romance into Latin). Such team work is revitalized today, for instance with the new Bible translation into French (2001) made in tandem by an exegete and a writer, or the new Ulysses (Joyce) by a team of eight translators (2004), or any localization project - working agents being in real and/or virtual contacts (Pym, 2004b: 171-172)

The tension between an individualistic and a collaborative approach to translation is not new, but we can observe that the former approach was dominant from the Renaissance to the end of the $20^{\text {th }}$ century, with an apogee during the Romantic period, when the writer was more and more idealized as a singular figure while translators work in cooperation with their editors and publishers, their national institutions or their peers. The latter approach seems to be expanding through the use of translation memory systems, cloud translation, fan sourcing, translation by web communities, etc.

In fact, and here comes my first question, why do we need a media technology history of translation? Practices of reading and writing have changed historically according to the material forms (human body, tablet, roll, codex, book, computer) available for the storage and retrieval of data and information. The hardware of these material forms (voice, clay, wax, papyrus, parchment, screen) always make a difference concerning how we read and write... and translate. We all know how Luther used the powerful combination of print and translation, and how Google uses the powerful combination of computer memory and calculation for Machine Translation.

Through cultural history, we can easily follow the influence of media technology in painting, but we seldom pay attention to similar influences in translating. Book historians have paved the way for such study - being aware of the changes in oral, scribal, print and screen cultures, but not yet translation historians (Cronin, 2003; Littau, 2011). Today, we can see that, as in the past, several media cultures coexist: paper and screen are struggling for the dominant position, just as individualistic and collaborative approaches 
still overlap. Here, we can refer to mediology as another inspiring source (Debray, 1991; 1994; 2004) that is challenging the conventional idea that "technology is not culture". Examining the methods used for the memorizing, transmission and displacement of cultural knowledge, mediology seeks to understand how media technology is not only storing but also directly enframing our thoughts, beliefs and social organisations.

Let us have some historical examples.

Cicero is often referred to as an initiator of the dilemma "sense for sense" as opposed to "wordfor-word". However we tend to forget that what we call now political, literary and philosophical interventions were public and oral - performed with bodily gestures. Oratorical skills were highly valued, and not only for lawyers. Cicero translated speeches into textual forms like an orator, that is, eloquence took precedence over fidelity (Cicero, 1949: 365; Weissbort and Eysteinsson, 2006: 21). Presumably, he composed orally and dictated his translation to somebody else who stored it on rolls to be read when the two wooden cylindrical sticks were held with both hands. In other words, translation was mediated by the technology of writing, and the text itself was mediated between two forms of oral delivery - as a speech and in the reading aloud act. We do not know the kind of translation that Cicero refers to (written or made public) when telling of his preference for translating sense for sense. Furthermore, we should not forget that he did not necessarily rely on a written text (original or a copy) but possibly on his memory in order to translate Aristotle's Topics. Working with and from voice and memory is highly dissimilar to our graphocentric perspective based on the scripted word and not on the memorized and oral word.

What about the medieval European culture, developed in general thanks to the handwritten codex, when translations were produced under a certain patronage (the Church, kings, princes, etc.)? The codex, with its illuminations and gold was made for a specific reader (the future owner) by several scribes and illustrators. We are then far from our book production aiming at an anonymous literary marketplace. Each codex was a unique artifact: its localized production involved personal relations and collaborative work. When an original codex was lost or only available as copies (reproductions with mistakes), the translator had to use different sources, more or less removed from the original: surviving fragments in different locations, other translations in different language or dialects, quotations embedded in other works, etc. The original could not stand as a standard against which the translation could be compared and evaluated (Ellis, 2000).

Codices both retained some parts of an oral tradition (promoting free adaptation) and introduced sometextual features of the printculture (promoting a more literal translation strategy) (Tymoczko, 2010: 219, 228; Hermans, 1992, 1997). The literalist approach was justified in a monastic scriptorial context in which faithfulness to the Word of God demanded a word-for-word translation. Between variations due to the way in which codices were produced and transmitted and the insistence of keeping strictly to as near the sacred text as possible, we can see how complex was the medieval translation situation. Hence, we have the different labels which appear at the time, such as compilatio, ordinatio (ordering), imitatio, etc. The manuscript culture allowed different forms of writing: glossing, translating, copying, authoring, etc., with the possibility of making omissions, additions and commentaries. Besides, parchments were becoming more popular than rolls: readers could have easier access to any part of the text. Little by little, pagination, tables of contents and so forth changed the codex and made it possible to gather several texts in a single volume. Further, since you could hold it with one 
hand only, the reader could make notes with the other hand (Cavallo, 1999: 88). The monastic habits of reading aloud shifted to scholastic habits (reading in a silent way and annotating).

What happens with the print culture?

The invention of typography in the mid$15^{\text {th }}$ century again changed the production, the consumption, the transmission and the transportation of texts. From then on, we could produce multiple copies that were identical. There could be spelling mistakes and changes in the printing process and also pirate and counterfeit editions; however, more importantly, the new medium increases the demand for reading material (RED). The vernacular languages became the languages of learning. In translation, the lay out of the original pages in Latin informed the translation strategy itself. Translation then became not only an inter-lingual process, but also an intra-medial transfer - as today with tourist brochures, comics, children's illustrated books, etc., where we prefer to talk about adaptation rather than translation!

In parallel with this evolution, we saw the rise of a literate bourgeoisie and in certain societies the emergence of a national language. Translations in that perspective serve a new kind of readership (Jouhaud \& Viala, 2002) and a certain ideology. Between the Renaissance and the mid-20th century, a model of translation was developed insisting on the confrontation of source and target, supporting theories of equivalence and the illusion of equal national languages (Pym, 2004a; 2004b: 173-174). Over several centuries, the circulation of texts accelerated. The business of bookselling and trading gave birth to secular literature (and also to periodicals and newspapers). The expansion of book production gained a new impetus with the invention of pulp and dime novels (around 1860) and paperback books (around 1950). In the $18-19^{\text {th }}$ centuries, translations were booming - as yet there were no legal mechanisms regulating the rights for a foreign work. "Active retranslations" (Pym, 1998: 82-83) are frequent in such a competitive markets. We are then far away from volumen (rolls) without punctuation and from codices with their illuminated letters.

Theneed for fast-reading silently was satisfied when printers and typesetters systematized and standardized layouts and spelling... and also when translators favoured fluency as the dominant strategy (Venuti, 2008).

Today, in our digital culture, fluency (aiming at readability) gives way to accessibility and usability, the focus being less on texts and more on users (readers and viewers). An electronic text (but not necessarily an e-book) can be reconfigured by its users thanks to hyperlinks (the text you read has no physical endings) and interactivity (the Internet invites readers to add their own words and images - to co-produce meanings). The traditional division of labour between creating a work (text, film, music, etc.), reproducing it and distributing it is blurred with the new technology now available. Crowdsourcing in translation is also changing translational procedures. In twenty years or so, computer technology has transformed our concepts of text and book and also our experience of reading, writing and translating. The translation act can be visible on the screen: readers, including other translators, can participate in the process and compare different translated versions, rather than confronting the source and target texts.

From Cicero to today, translation has always borne the traces of its technological environment. We have given very little attention to the different distinct periods of history, but we must insist again that there is no clear cut correspondence between a technology and a period of time: several media coexist in a given culture at a given time. The linear way in which I have presented phenomena and examples should not give the impression of 
monolithic space and time. In fact, as we know, there is always a different translation ethos in a certain period. The same should also apply to interpreting - oral performance-based for a very long time but now under pressure from various media (from telephone to speech recognition systems, from on-line resources to interpreting in virtual reality) (Baber, 2010). In both cases, strategies, evaluation criteria and the popular perception of the practices are changing.

\section{A new relationship between oral and written codes}

The history of the conditions of reading, authorship and publishing also sheds light on the relationship between oral and written codes. The overwhelming fact of human language has been its orality. However, our Western society, with the invention of printing, has rejected orality studies. In Translation Studies, we still tend to focus exclusively on text, or rather on a certain concept of text and neglect oral and/or written translation of oral narratives and epics (Tymoczko, 1990; Bandia, 2011). Even in Interpreting Studies, long dominated by the paradigm of conference interpreting, the psychodynamics of orality has been under-evaluated.

I shall now deal with three different aspects of the relationship:

- Language categorization and boundaries

- New formats and genres in which oral and written codes are interplaying

- A new concept of text - or towards one.

\section{Language categorization \\ and boundaries}

Before we can talk about language barriers, language planning (encompassing status and corpus planning), language management, language standardization, and language diversity, we need to examine how languages are categorized - creating lines across which comprehension is impeded because of language differences.

In the Early Middle Ages, we regulated cross-cultural communications by a certain hierarchy of languages, with at the top languages closest to divine inspiration (Hebrew, Greek, Latin), then the vernaculars based on Latin, and then the patois. Today, the hierarchy still exists, though inspired rather more by technology than God: there is the lingua franca allowing "internationalization" of business and products, then languages which warrant full localization, languages that have partial localization and languages which remain unlocalized.

The Renaissance was the age of the vernaculars - in principle, equal in value; however, at the same time, the concept of the Nation-State was emergent, with language as one of its characteristics. Translators as intermediaries began to be thrown into a kind of double-bind: their language loyalty contradicted national borders since their identification was two-sided.

The association between state, nation, territory, language, and culture rejected the possible cline between languages, and led to typologies of languages, with different degrees of legitimation, as if languages could truly be isolated and categorized. Dialects, patois and standard forms were more and more connoted, anchored in a certain linguistic and political ideology - hence discrete categories such as, to give contemporary examples, Serbo-Croatian, Serbian, Bosnian, Croatian or Belgian French, Québécois, français branché - all varieties of the same "language" or different languages. From the $13^{\text {th }}$ century with Dante Alighieri in his De Vulgari Eloquentia, where he divided languages between si, oc and oill languages, to the $18-19^{\text {th }}$ century, with genetic categorizations (William Jones, Franz Bopp) and different typologies (for instance by the brothers Von Schlegel), languages have been defined to fit certain political agendas. 
Antoine Meillet (1928) identified two types of languages: on the one hand, dominant languages, written languages, main national languages, and on the other hand, spoken languages, dialects, popular languages, local languages, etc. In the list, we clearly have a hierarchy of languages between the most prestigious languages (Latin, Greek, "civilized" languages) and the most stigmatized ones (popular languages), with the national languages lying between.

Translation Studies is largely based implicitly on such categorizations, not to mention the emphasis on literature.

\section{Interplay between oral}

and written codes

Orality and written form have never been homogeneous (Ong, 1982; Goody, 1987). You can speak spontaneously in a dialogue or a monologue, or by reciting, reading aloud what has been written. You can write in order to be read, to be spoken as if not written, etc. For a long time, studies have been carried out on the (realistic) representation, simulation or transcription in written texts (novels, dramas, film scripts), or how syntax and typography could show discontinuity of the verbal flow. Very few works have focused on how orality is embedded and then rendered in translation (Brumme et al. 2008, 2012; Gambier \& Lautenbacher, 2010). However, today these conventions and strategies are shaken up by new hybrid forms of communication which force us to rethink the oral nature of our interactions and challenge the ideology of literacy and the power ascribed to it (Monod, 2013). I am here referring to emails, SMS, chats, blogs, tweets, and interactive games in which different spellings, emoticons, avatars, acronyms, abbreviations, punctuation, capital letters, interjections, etc. are used in an expressive, deictic or emblematic way.

Languages on-line and computer-mediatedcommunications (CMC) are new vernacular practices: the on-line world has effects on our natural languages, how we identify ourselves, how we make assumptions (Barton \& Lee, 2013). A new analogy can be drawn between physical, non-verbal gestures and the textual conventions of new and social media: digital and social media texts are conversational texts, too often understood and approached as "disembodied". The mediated/ embodied binary is a false dichotomy, as much as is the so-called opposition between oral and written. The text-based CMC is a written-oral hybrid where emotions, thoughts and social cognition are intimately bound. In the current evolution of our communication technologies, providing new ways of "keeping in touch", we are witnessing the closing of the "Gutenberg parenthesis" (Pettitt, 2009): We are not writing texts but sending words.

We cannot exclude from these changes the fact that literature itself is changing, ranging from cyber-literature - for example Steve Tomasula (2010): TOC: A Media-novel, a mosaic of texts, medias, and collaborators, where the author's role is multiple: writer, conductor, producer, art director, etc. - to art installations combining design and literary texts. Poetry can also be staged as an aural performance (cf. slam, rap), as a public lecture, or as a visual display (Lee, 2013). Keitai Shousetsu is now the name in Japan for novels in SMS writing, delivered and serialized on mobile phones, and published as serials in newspapers as were certain novels in France during the $19^{\text {th }}$ century.

What about translation and interpreting in this moving landscape, from the "graphosphère" to the "videosphère" (Debray, 1994)? There are a number of practices that blur the traditional opposition between the oral and the written (which is still the basis of separate lines in training programmes: translation (first the written) or how to reformulate, and then interpreting (oral) or how to re-express): 
- Consecutive interpreting, where notes serve for oral delivery;

- simultaneous interpreting, which sometimes depends on a planned, written speech, read by the speaker;

- sight translation or prima vista, as a dichotomous process of language (from the source to the target language) as well as from a written into an oral form;

- court interpreting, where the interpreters work from written documents to crossexamination of witnesses, defendants, etc.;

- translating theatre, comics, songs, operas where several types of signs coexist (aural, visual, musical, etc.) and where acceptability is less important than speakability, performability and singability;

- translating oral literature (already "translated" into texts);

- localizing video games (their rules, their user interface: menu items and help messages, their warning messages, their instructions, their manual, their story, their dialogues, their texts in images, their voice-over, etc.);

- live subtitling and intra- and inter-lingual subtitling (from dialogues to the written lines at the bottom or the side of the screen).

Some tools also disturb the border between oral and written, that is speech recognition software, in other words speaking what will become a written text. Coupled with Machine Translation, we can easily imagine how this would change conference interpreting in certain settings.

I would like here to refer to Miriam Shlesinger: from her MA thesis (1989) to her article published in 2012, she has constantly questioned the oral-written continuum and wondered about interpreting as a distinct linguistic, cognitive and textual phenomenon. We can also recall A. Chesterman's call for research that would include the two modalities and reinforce the interconnectedness between translation and interpreting studies (Chesterman, 2004). Finally, why not to mention works such as D. Robinson (1997/2012; 2001) and C. Scott (2012), who are insisting on reading as a physio-psychological experience and on the importance of rhythm in speaking and writing?

\section{A new concept of text}

We have used the term text many times in our presentation. It is now time to wonder about its polysemy and our assumptions (Toury, 2006). Does text mean the same thing today in literary translation, conference interpreting, audiovisual translation and localization? What is the relationship between the elements in the continuum of author-translator-reader in the different concepts of text?

In text linguistics, text (understood as a mono-modal verbal written text) was defined by seven standards of textuality: cohesion, coherence, intentionality, acceptability, informativity, situationality, and intertextuality (Beaugrande \& Dressler, 1981). These were made relevant for translation by Hatim \& Mason (1990) and Neubert \& Shreve (1992). However, there are differences between a text by Cicero or Virgil - to be read aloud during a special (political, religious, aesthetic) event and a text written by M. Proust, between a traditional literary text in a book and a text giving instructions or information. All these texts however are materially (physically) finite (self-contained) and semantically open, whereas hypertexts are both materially and semantically open. Today, one does not read an e-text without a bonus referring to an interview on You Tube, a soundtrack, a public reading, a map (just as you 
do not watch a film on a DVD without rushes, a clip, etc.).

The concept of text in paradigms of Translation Studies changes according to the approaches (descriptive, systemic, postcolonial, feminist, etc.) and over time. Obviously, within the perspective of equivalence, and the confusion between source text and target text (as linear arrangements of verbal units) and within the perspective of domestication of tourist brochures, art books, exhibition catalogues, advertisements combining writing and illustrations (photos and drawings), the concept of text has slightly changed.

Text as renewed through ICT has become poly-semiotic or multimodal. Two decades with the Internet and the Web have transformed a concept that has been dominant for more than a thousand years. We now have texts made of short messages (blogs, tweets), of still and moving images, sounds, pictograms, tables, playing with different colours and fonts, etc. In a way, hypertexts recreate the ambiguities of medieval manuscripts - it was not always easy to differentiate between author and copyists, between original knowledge and commentaries. In addition, today the same text can also be multimedia: for example, a press article with photos can be transferred from a newspaper to a web site or a smartphone.

The relationship between the verbal and other semiotic modes of communication was hierarchical and asymmetric for R. Barthes (1977), who postulated the domination of verbal text over the other semiotic codes - the text functioning as a relay (text and image stand in a complementary relation) and an anchorage (the text orientates the reading of an image). Today, scholars in multimodal studies, such as e.g. Kress \& van Leeuwen (1996; 2001), highlight the primacy and autonomy of visual signs. The question here is not to determine who is right but to observe that both trends point to the importance of considering multiple modes of representation in tandem - verbal forms no longer constitute the only way of producing meaning.

Mono-modality cannot be an approach to texts, even for certain literary writings. Similarly, translation cannot be rooted exclusively in the written verbal text. In Interpreting Studies, we now acknowledge the weight of non-verbal features of multilingual communications. I. Kurz and F. Pöchhacker (1995), for instance, have defined eight quality criteria for spoken media interpreting: comprehensibility, synchronicity, complete information, smooth delivery, appropriate facial expressions, standard signing, elegance and dress code; however, is the interpreter always visible on the TV screen?

The transformation of the concept of text goes with the renewal of genres, especially the web-mediated genres.

\section{Implications}

What could be the consequences of the new perspectives offered by a media history of translation and suggested by the challenging interface between the written and the oral? Two main issues will be considered here.

\section{Ethical implications}

One of the main dilemmas of interpreting has been, and still is for many, how to say "I" (the speaker) and pretend to be a specific voice? The metaphors of the interpreter as a conduit, a ghost or a parrot belong to the past, at least among interpreters. In addition, quite a number of publications in the last decade have criticized the "neutrality" of the interpreters but not their visibility (in the booth, near the speaker, behind or close to the doctor, etc.). Neutrality or impartiality can be defined as loyalty to what the speaker says, not interfering in the message to convey, or as the non-taking of a stand on the issue raised in 
the speech. This is a narrow and unbenevolent definition which should not be confused with the fact that understanding and reformulating (keeping in mind that the two different language systems do not convey information in the same way) and empathy (or not) imply the presence and the voice of the interpreter/translator, for instance in the decision-making process and the selection of words in the target language. In different settings (courtroom, hospital, police station, conference venue, embassy, lecture room, or war room, etc.) the interpreters cannot deny their values, their ideology. Interpreting takes place in an interactive situation, even during a conference, with different agents playing different roles.

My point here is not to bring empirical evidence for or against "neutrality" but to admit that new technologies (interpreting by phone, Skype, video) and many new different social multilingual encounters have created new situations for research. On the one hand, we have conference interpreters defending their reserved area (see EMCI based on exclusion), and then, on the other hand, we have dialogue interpreters providing services in signed and natural languages in more and more open spaces. The role and the position of the interpreters are changing as a result of the technologies and increased mobility in a globalized world. Between the sheer neutrality claimed yesterday and the political activism claimed today by certain interpreters, there is a cline of different types of mediation where the established power relationship between the agents is always a challenge.

Several publications have already dealt with the role, the professional status and the recognition of interpreters when working for a State that seeks to respond to the needs of multilingual communications, when working in a face-threatening situation, when working in an adversarial setting in which individuals rights are at stake, etc. The move between norms and obligations (an interpreter should be or not be this or that, behave in such and such a manner) on the one hand and presence and voicing on the other is not a static one: it constantly exceeds the simplistic dichotomies (neutrality/activism, invisibility/ visibility, discretion/commitment) and the numerous labels, such as messengers, interveners, agents, professionals, mediators, inbetweens, etc.

From the eruption of social networks to globalization, crowdsourcing, and Machine Translation, our work must deal with new issues that call for a reassessment of the existing ethical discourse - either too simplistic or too essentialist. It is reflecting on what has been said and written, revisiting or deconstructing a number of concepts and proceeding towards the construction of new descriptions and explanations, or new principles such as the five put forward by A. Pym (2012: 166-167) about the responsibilities of translators/ interpreters.

\section{Implications in training}

The shift from linguistic text to multimodal text, from an analogue to a digital culture, and the changes in the consumption and distribution of translated texts, the collaborative forms of translation - boosting the visibility of translation - and interpreting in new settings have consequences in the training. I will limit myself to two remarks here.

Firstly, we do not yet have any comparative studies on non-trained translators and trained ones. What will be the validity of our training programmes if and when our students have been amateur translators for some time? Will their concept of translation match the ways we train and theorize? Perhaps an introduction to the media history of translation and interpreting could help to give perspectives on the methodology and explain certain concepts, such as equivalence, fluency and invisibility. 
How can we cope with the different types of would-be and professional translators in need of lifelong training? Until today, we have studied the acquisition of competences, the transition from novices to professionals as two distinct homogenous groups; however, can we focus only on the translating process and ignore the profiles, the representations of the learners?

Secondly, among the various competences of the translator, one could become predominant: that of reading skill and the aptitude to understand what is to be translated. Understanding calls for knowledge, memory, inference and calculations. But reading the Internet promotes a fragmented way of reading through a string of links, mainly for searching for limited and selective information. What would happen when you need to understand a full document in depth? Again, there could be a tension, in a transition period like ours, between different skills: on the one hand in reading and on the other hand in understanding a multilingual document.

Types of translation (including Machine Translation), oral and written in new configurations, English as a lingua franca, directionality in interpreting when there are more and more bilingual and bicultural students - the number of issues to be anticipated and dealt with is increasing, even after threeto-four decades of research in Translation Studies.

To sum up, I would like to return to one of Miriam Shlesinger's latest articles in which she insisted why, how and what researchers and practitioners could learn from one another (2009). As she wrote, repeating what she had claimed as long ago as 2004 (p. 117), the "interrelationship between the academic investigation of interpreting [let us add translation] and the practitioner's experiences is not new of course, but...it merits being reviewed periodically." That is the only way to overcome the paradoxes of our fields (Translation and Interpreting Studies together) - facing the diversity of the disciplines addressed, the diversity of research relevance, the diversity of research discourses (Gambier, 2004). Today, the changes are so rapid, so complex, so sensitive and so controversial that it is sometimes difficult to follow and understand what is going on. Maybe looking back at history in the longterm (longue durée as used by the French Annales school of history writing) and jettisoning our obsession with fixed verbal texts are also ways to cross the divide and view the future with confidence.

\section{References}

1. Bandia, Paul. 2011. "Orality and Translation”, in: Gambier, Yves \& van Doorslaer, Luc (eds). Handbook of Translation Studies, vol. 2. Amsterdam / Philadelphia: John Benjamins, 108-112. Also accessible on-line: www.benjamins.com/online/hts

2. Barthes, Roland. 1977. "Rhetoric of the image" (original in French: 1964), in: Roland Barthes. Image-Music-Text (twelve essays selected and translated by S. Heath), 32-51. London: Fontana Press.

3. Barton, David \& Lee, Carmen. 2013. Language on line. Investigating Digital Texts and Practices. London: Routledge.

4. Beaugrande, Robert \& Dressler, Wolfgang. 1981. Introduction to Text Linguistics. London: Longman.

5. Berber, Diana. 2010. Information and communication technologies in conference interpreting. A survey of their usage in professional and educational settings. Saarbrücken: LAP Lambert Academic Publishing. 
6. Brumme, Jenny (ed.). 2008. La oralidad fingida. Descripción y traducción. Teatro, cómic, y medias audiovisuales. Madrid: Iberoamericana \& Frankfurt: Vervuert.

7. Brumme, Jenny \& Espunya, Anna (eds). 2012. The Translation of Fictive Dialogue. Amsterdam: Rodopi.

8. Brumme, Jenny \& Resinger, Hiledgard (eds). 2010. La oralidad fingida. Obras literarias. Madrid: Iberoamericana \& Frankfurt: Vervuert.

9. Cavallo, Gugliemo. 1999. "Between volumen and codex: Reading in the Roman world", in: G. Cavallo \& Roger Chartier (eds). A history of reading in the West, translated from Spanish (1998) by Lydia G. Cochrane. Cambridge: Polity Press, 64-89.

10. Chesterman, Andrew. 2004. "Paradigm problems?”, in: C. Schäffner (ed.), 52-56.

11. Cicero. 1949. On invention. The best kind of orator. Topics. Rhetorical treatises. Translated from Latin by H.M. Hubbell. Cambridge, MA: Harvard University Press.

12. Cronin, Michael. 2003. "The Empire talks back. Orality, heteronomy and the cultural turn in Interpreting Studies", in M. Tymosczko \& E. Gentzler (eds). Translation and Power. Amherst, MA: University of Massachusetts Press, 45-62.

13. Debray, Régis. 1991. Cours de médiologie. Paris: Gallimard.

14. Debray, Régis. 1994. Manifeste de médiologie. Paris: Gallimard.

15. Debray, Régis. 2004. Transmitting cultures. Translated from French: Transmettre (1997/2000), by Eric Rauth. New York: University of Columbia Press.

16. Ellis, Roger. 2000. “The Middle Ages”, in: Peter France (ed.).The Oxford Guide to Literary in English Translation. Oxford: Oxford University Press, 39-45.

17. Gambier, Yves. 2004. "A succession of paradoxes”, in: C. Schäffner (ed.), 62-70.

18. Gambier, Yves \& Lautenbacher (eds). 2010. “Oralité et écrit en traduction” (special issue), Glottopol 15, on-line journal: http://www.univ-rouen.fr/dyalang/glottopol/numero_15.html

19. Goody, Jack. 1987. The interface between the written and the oral. Cambridge: Cambridge University Press.

20. Hatim, Basil \& Mason, Ian. 1990. Discourse and the translator. London: Longman.

21. Hermans, Theo. 1992. "Renaissance translation between literalism and imitation", in: Harald Kittel (ed.). Geschichte, System, Literarische Übersetzung. Histories, systems, literary translations. Berlin: Erich Schmidt, 95-116.

22. Hermans, Theo. 1997. "The task of the translator in the European Renaissance. Explorations in a discursive field”, in: Susan Bassnett (ed.). Translating Literature. Cambridge: D.S. Brewer. 14-40.

23. Jouhaud, Christian \& Viala, Alain (eds.) 2002. De la publication. Entre Renaissance et Lumières. Paris : Fayard.

24. Kress, Gunther \& van Leeuwen, Theo. 1996. Reading Images. The Grammar of Visual Design. London: Routledge.

25. Kress, Gunther \& van Leeuwen, Theo. 2001. Multimodal Discourse: The Modes and Media of Contemporary Communications. London: Arnold.

26. Lee, Tong-King. 2013. "Performing multimodality: Literary translation, intersemioticity and technology”, Perspectives 21 (2), 241-256.

27. Littau, Karin. 2011. "First steps towards a media history of translation", Translation Studies 4 (3), 261-281.

$$
-359-
$$


28. Meillet, Antoine. 1918/1928. Les langues dans l'Europe nouvelle. Paris : Payot.

29. Monod, Jean-Claude. 2013. Ecrire. A l'heure de tout message. Paris: Flammarion.

30. Neubert, Albrecht \& Shreve, Gregory. 1992. Translation as Text. Kent: Kent State University Press.

31. Ong, Walter. 1982. Orality and literacy. The technologizing of the word. London: Methuen.

32. Pettitt, Tom. 2009. "Reformulating the Gutenberg parenthesis", presented at Media in Transition 6:

33. Stone and Papyrus, Storage and Transmission, April 24-26, 2009. Available at http://web.mit. edu/comm-forum/forums/gutenberg.html (Accessed 18 October 2013).

34. Pym, Anthony. 1998. Method in Translation History. Manchester: St Jerome.

35. Pym, Anthony. 2004a. "The Medieval Postmodern in Translation Studies". Accessed 13 October 2013: www.tinet.cat/ apym/on-line/translation/2004_medieval.doc

36. Pym, Anthony. 2004b. The Moving Text. Localization, translation, and distribution. Amsterdam / Philadelphia: John Benjamins.

37. Pym, Anthony. 2012. On translator ethics. Amsterdam/Philadelphia: john Benjamins.

38. RED. The Reading Experience Data Base 1450-1945. Launched in 1996 at the UK Open University. Available at http://www.open.ac.uk/Arts/RED/index.html

39. Robinson, Douglas. 1997/2003/2012 ( $3^{\text {rd }}$ edition). Becoming a Translator. An introduction to the theory and practice of translation. London: Routledge.

40. Robinson, Douglas. 2001. Who translates? Translator subjectivities beyond reason. Albany: SUNY Press.

41. Schäffner, Christina (ed.). 2004. Translation Research and Interpreting Research. Traditions, Gaps, and Synergies. Clevedon: Multilingual Matters.

42. Scott, Cline. 2012. Translating the perception of text. Literary translation and Phenomenology. London: Legenda (Modern Humanities Research Association and Maney Publishing).

43. Shlesinger, Miriam. 1989. Simultaneous interpretation as a factor in effecting shifts in the position of texts in the oral-literate continuum. Unpublished MA thesis. Tel Aviv University.

44. Shlesinger, Miriam. 2004. "Doorstep Inter-subdisciplinarity and beyond", in: C. Schäffner (ed.), 116-123.

45. Shlesinger, Miriam. 2009. "Crossing the divide: What researchers and practitioners can learn from one another", Translation and Interpreting 1 (1), 15 pages. Online: http://www.trans-int.org

46. Shlesinger, Miriam \& Ordan, Noam. 2012. “More spoken or more translated?”, Target 24 (1), 43-60.

47. Toury, Gideon. 2006. "Conducting research on a "wish-to-understand" basis", in: Duarte João, Assis Rosa Alexandra, Seruya Teresa (eds). Translation Studies at the Interface of Disciplines, 55-66. Amsterdam/Philadelphia: John Benjamins.

48. Tymoczko, Maria. 1990. "Translation in Oral Tradition as a Touchstone for Translation Theory and Practice”, in: Bassnett, Susan \& Lefevere, André (eds) Translation, History and Culture, 46-55. Pinter Publishers.

49. Tymoczko, Maria. 2010. "Ideology and the position of the translator: In what sense is a translator in-between?", in: Mona Baker (ed.). Critical readings in translation studies. London: Routledge, 213-228. 
50. Venuti, Lawrence. 2008 (1995). The translator's invisibility. A history of translation. London: Routledge.

51. Weissbort, Daniel \& Eysteinsson, Astradur (eds). 2006. Translation - Theory and practice. An historical reader. Oxford: Oxford University Press.

\section{За пределами: парадоксы и вызовы}

\section{Ив Гамбье}

Университет Турку

Финляндия, 20500, Турку, Коскениеменкату, 4

Устное и письменное переводоведение в настоящее время сталкивается с профессиональными, социально-профессиональными, сочиально-политическими, технологическими и педагогическими вызовами. Настоящая статья пытается ответить на три вопроса, основанных на данных вызовах:

- Почему нам нужна медийная истории перевода?

- В какой степени на переводоведение влияют новые отношения между устными и письменными кодами?

- Какими возможные этические и методологические выводы могут быть сделаны?

Эти три вопроса обладают общим знаменателем: информационная и коммуникационная технология (ИКТ), которая размывает наши традиционные границы и категории.

Ключевые слова: ичифровая культура, языковая категоризация, медийная история, устные/ письменные коды, текст, этика переводчика.

Научная специильность: 10.00.00 - филологические науки. 